\title{
CAMA
}

Centre for Applied Macroeconomic Analysis

\section{How Important are Spillovers from Major Emerging Markets?}

\section{CAMA Working Paper 37/2017 May 2017}

Raju Huidrom

World Bank, Development Prospects Group

\section{Ayhan Kose}

World Bank, Development Prospects Group

Brookings Institution

CEPR and

Centre for Applied Macroeconomic Analysis, ANU

\section{Franziska Ohnsorge}

World Bank, Development Prospects Group and

Centre for Applied Macroeconomic Analysis, ANU

\section{Abstract}

The seven largest emerging market economies - China, India, Brazil, Russia, Mexico, Indonesia, and Turkey - constituted more than one-quarter of global output and more than half of global output growth during 2010-15. These emerging markets, which we call EM7, are also closely integrated with other countries, especially with other emerging and frontier markets. Given their size and integration, growth in EM7 could have significant cross-border spillovers. We provide empirical estimates of these spillovers using a Bayesian vector autoregression model. We report three main results. First, spillovers from EM7 are sizeable: a 1 percentage point increase in EM7 growth is associated with a 0.9 percentage point increase in growth in other emerging and frontier markets and a 0.6 percentage point increase in world growth at the end of three years. Second, sizeable as they are, spillovers from EM7 are still smaller than those from G7 countries (Group of Seven of advanced economies). Specifically, growth in other emerging and frontier markets, and the global economy would increase by one-half to three times more due to a similarly sized increase in G7 growth. Third, among the EM7, spillovers from China are the largest and permeate globally. 


\section{Keywords}

Business cycles, spillovers, external shocks, China, EM7, G7

\section{JEL Classification}

E32, F20,F42

\section{Address for correspondence:}

(E) cama.admin@anu.edu.au

ISSN 2206-0332

The Centre for Applied Macroeconomic Analysis in the Crawford School of Public Policy has been established to build strong links between professional macroeconomists. It provides a forum for quality macroeconomic research and discussion of policy issues between academia, government and the private sector.

The Crawford School of Public Policy is the Australian National University's public policy school, serving and influencing Australia, Asia and the Pacific through advanced policy research, graduate and executive education, and policy impact. 


\title{
How Important are Spillovers from Major Emerging Markets?
}

\author{
Raju Huidrom, M. Ayhan Kose, and Franziska L. Ohnsorge*
}

May 2017

\begin{abstract}
The seven largest emerging market economies - China, India, Brazil, Russia, Mexico, Indonesia, and Turkey - constituted more than one-quarter of global output and more than half of global output growth during 2010-15. These emerging markets, which we call EM7, are also closely integrated with other countries, especially with other emerging and frontier markets. Given their size and integration, growth in EM7 could have significant cross-border spillovers. We provide empirical estimates of these spillovers using a Bayesian vector autoregression model. We report three main results. First, spillovers from EM7 are sizeable: a 1 percentage point increase in EM7 growth is associated with a 0.9 percentage point increase in growth in other emerging and frontier markets and a 0.6 percentage point increase in world growth at the end of three years. Second, sizeable as they are, spillovers from EM7 are still smaller than those from G7 countries (Group of Seven of advanced economies). Specifically, growth in other emerging and frontier markets, and the global economy would increase by one-half to three times more due to a similarly sized increase in G7 growth. Third, among the EM7, spillovers from China are the largest and permeate globally.
\end{abstract}

Key Words: Business cycles; spillovers; external shocks; China; EM7; G7.

JEL Codes: E32, F20, F42.

\footnotetext{
${ }^{*}$ Huidrom: World Bank, Development Prospects Group; rhuidrom@worldbank.org. Kose: World Bank, Development Prospects Group; Brookings Institution; CEPR, and CAMA; akose@worldbank.org. Ohnsorge: World Bank, Development Prospects Group; CAMA; fohnsorge@worldbank.org. Earlier drafts benefited from comments by Ajai Chopra, Kevin Clinton, Aart Kraay, Jaime Marquez, Warwick McKibbin, Peter Morgan, Cyn-Young Park, David Robinson, Luis Serven, Marc Stocker, Carlos Vegh, Naoyuki Yoshino, and participants at the ADB-ADBI conference on "20 Years after the Asian Financial Crisis", ECB-Central Bank of Turkey Conference on "Economic Growth and Income Convergence", and the CAMA-ANU-Australian Treasury Conference on "Shaping the Next Decade: Economic Trends in the Global Economy," and at seminars at the ADBI, Bank of England, Bank of Japan, Federal Reserve Board, IMF, Japan Ministry of Finance, Johns Hopkins SAIS, and World Bank. We thank Sergio Kurlat and Qian Li for outstanding research assistance. The findings, interpretations, and conclusions expressed in this paper are those of the authors. They do not necessarily represent the views of the World Bank, its Executive Directors, or the countries they represent.
} 


\section{Introduction}

In the last two decades, emerging market economies played an increasingly important role in the global economy. They constituted more than a quarter of global output and more than half of global output growth during 2010-15, compared with just about one-tenth and one-fifth respectively in the 1990s (Figure 1). The rising importance of emerging markets is also accompanied by their rapid integration into global trade and finance networks. The seven largest emerging market economiesChina, Russia, India, Brazil, Turkey, Mexico, and Indonesia - constitute about 80 percent of total emerging market output. This group, which we label as EM7, akin to G7 (the Group of Seven major advanced economies), has also been the main source of growth in emerging markets and their integration into the global economy. ${ }^{1}$ In particular, the EM7 economies have strong trade and financial ties with other emerging markets (EM) and frontier markets (FM), especially with those in their respective neighborhoods. ${ }^{2}$ Given their size and integration, growth in EM7 could have significant spillovers to other economies in the world. ${ }^{3}$ The objective of this paper is to empirically assess the size of these spillovers.

Previous studies on spillovers mostly focus on those originating from advanced economies, including the G7, while spillovers from the emerging markets have received relatively scant attention. ${ }^{4}$ This reflects the dominant historical role of the G7 economies in the world economy. However, given the changing economic landscape, understanding spillovers from the EM7 has become increasingly important. Existing work on spillovers from the EM7 is limited, tends to focus on spillovers from individual EM7 economies, and are often conducted with a regional perspective. The literature so far has not presented a systematic analysis comparing individual EM7 economies as sources of spillovers, and comparing spillovers from the EM7 to those originating from the G7. Our paper is the first one that attempts to fill these gaps in the literature.

An extensive literature employs dynamic stochastic general equilibrium (DSGE) models to quantify and elucidate the role of specific shocks in driving business cycles. In particular, some studies have examined the role of domestic and foreign shocks using multi-country DSGE models mostly in the context of advanced economies (e.g. Ambler, Cardia and Zimmermann 2002; De Walque, Smets, and Wouters 2005). While these are useful for understanding spillovers among advanced economies, there is less theoretical work that looks at spillovers between advanced and emerging markets, and within emerging markets (Comin et al. 2014). Specifications and evaluations

\footnotetext{
${ }^{1}$ The largest EM economies, i.e. EM7, are identified using 2015 GDP data at market exchange rates. In terms of economic size, the G7 constitutes roughly 80 percent of output in advanced markets (AM) which is also about the share of EM7 in total EM output. The G7 and EM7 are also the major sources of AM and EM integration into the global economy (Figure $1 \mathrm{C}$ and D). We consider these similarities to motivate the EM7 as a group that represents the major EM, as much as the G7 represents the major AM. The G7 and EM7 are also similar to the extent that they are, on aggregate, net-commodity importers, more specifically net-oil importers. For more detailed discussions of the rising importance of emerging markets in the global economy, see Kose and Prasad (2010), Magnus (2011), and Sharma (2012).

${ }^{2}$ Details of the country classification are provided in Table A1 in the Supplementary Appendix.

${ }^{3}$ Outside of EM7, the next three largest EM economies - Saudi Arabia, Poland, and Thailand - are relatively small, contributing on average less than 2 percent to EM output (Figure A5 in the Supplementary Appendix). For comparison, the next three largest AM economies outside of the G7 are also relatively small, and their contribution to AM output is quite similar, around 3 percent.

${ }^{4}$ For the literature on spillovers from advanced economies, see Canova (2005), Gregory, Head and Reynauld (1997), Stock and Watson (2005), Eickmeier (2007), Kose, Otrok and Whiteman (2003), and Diebold and Yilmaz (2015). Inoue, Kaya, and Ohshige (2015) and Ahuja and Nabar (2012) examine spillovers from China, and Alturki, EspinosaBowen, and Ilahi (2009) look at spillovers from Russia.
} 
of these models - especially in terms of shocks and comparison of simulated and actual momentsoften remain an open question. In this context, empirical estimates of spillovers using reduced-form models provide useful guidance for theoretical work (Canova and Marrinan 1998). Our empirical findings thus provide ground work for the specification and evaluation of DSGE models that feature both advanced and emerging market economies. ${ }^{5}$

To estimate spillovers from EM7, we use a parsimonious Bayesian vector autoregressive (VAR) model. The model features growth in EM7, other emerging and frontier markets (EFM), and G7 (representing the major advanced economies) plus additional controls for global financing conditions and commodity prices. The set of variables included in the VAR is consistent with that of a standard small open economy DSGE model that is calibrated to capture the main features of most of the EFMs included in our sample (Kose 2002; Neumeyer and Perri 2005). Exogenous shocks to EM7 growth are first identified using a recursive identification scheme in the model, and then the dynamic effects of those shocks on growth in other economies (i.e. spillovers) are traced out. We estimate the model using data over the period 2000Q1-2015Q2 for G7 economies and 16 EFMs. We employ the same model to estimate spillovers originating from G7 and compare the size of G7 spillovers with those originating from EM7. We use a similar model to estimate and compare spillovers from individual EM7 economies. Thus, our empirical approach utilizes a common methodology that allows a disciplined comparison of spillovers originating from the EM7 and G7, and also from the individual EM7 economies.

Our main findings are as follows: First, spillovers from EM7 are significant: a 1 percentage point increase in EM7 growth is associated with a 0.9 percentage point increase in growth in other EFM and a 0.6 percentage point increase in world growth at the end of three years. Second, notwithstanding sizeable spillovers from EM7 to other EFM, spillovers originating from G7 economies are larger. Specifically, a 1 percentage point increase in G7 growth is associated with an increase in growth in other EFM and the global economy that is one-half to three times larger than a similarly sized increase in EM7 growth. Moreover, fluctuations in G7 growth explain a much larger fraction, about four times, of the variance of growth in other EFM and the global economy than fluctuations in EM7 growth. Third, among the EM7, spillovers from China are the largest and permeate globally, but spillovers originating from the other EM7 are much smaller.

The rest of the paper is organized as follows. Section 2 describes the econometric methodology and the database. We present the empirical results in Section 3. In Section 4, we discuss the robustness exercises. Section 5 concludes.

\section{Methodology and Database}

We use a set of Bayesian structural vector autoregression (VAR) models to quantify growth spillovers from EM7 to other economies in the world. ${ }^{6}$ In this section, we describe the VAR models and the database used for estimation.

\footnotetext{
${ }^{5}$ Economic theory is ambiguous about the implications of increased trade and financial linkages for spillovers (Frankel and Rose 1998; Doyle and Faust 2002; Kose, Prasad, and Terrones 2009). Our study is also related to this literature as it is useful in quantifying the magnitude of spillovers.

${ }^{6}$ An alternative empirical approach for measuring spillovers is a panel regression framework. Compared with a structural VAR, the identification of exogenous growth shocks and tracing their dynamic effects are less straightforward. A related empirical approach is a dynamic factor model. Compared with a structural VAR, dynamic factor models are more useful in quantifying comovement among a large set of variables, but they are less useful for analyzing cross-border spillovers unless these spillovers are explicitly modeled.
} 


\subsection{VAR Models}

The VAR models, in reduced-form, can be represented as follows:

$$
y_{t}=a_{0}+A_{1} y_{t-1}+A_{2} y_{t-2}+\ldots+A_{p} y_{t-p}+u_{t},
$$

where $y_{t}$ is an $m \times 1$ vector of variables at date $t, A_{i}$ is an $m \times m$ coefficient matrix for each lag of the variable vector with $a_{0}$ being the constant term. The vector $u_{t}$ represents the reduced form error terms with a variance-covariance matrix (with off-diagonal entries) denoted by $\Omega$. The recursive identification scheme used in the paper amounts to using the cholesky factor of $\Omega$ to obtain a mapping from the correlated reduced-form error terms $u_{t}$ to the uncorrelated structural shocks $v_{t}$. The dynamic effects of these structural shocks on model variables are what we use to make causal inferences about how EM7 growth shocks affect growth in other economies, i.e. spillovers.

We estimate two types of VAR models depending on how other EFM are included in the model as spillover destinations. The first one which we label the aggregate model is used to study the aggregate spillover implications for other EFM as a group. That is, we use the aggregate model to measure how growth in EM7 affects, i.e. spills over to, aggregate growth in other EFM, where aggregate growth in other EFM is defined as the GDP weighted average of growth in individual economies in that group. For this, we include aggregate growth in other EFM as spillover destination in the model.

The second one which we label as the country model is used to estimate spillovers to individual EFM economies. Here, we include growth in each EFM economy as the spillover destination and the VAR model is estimated one at a time for each of these spillover destinations. While the aggregate model provides a summary estimate of aggregate spillovers to other EFM, the country model lends a much more disaggregated picture. We deploy both versions of the model to make robust inferences about spillovers. We now describe the two types of VAR models in much more detail.

Aggregate model. We include the following variables in vector $y_{t}$, in this order: G7 growth, the U.S. interest rate, Emerging Market Bond Index (EMBI), EM7 growth, oil price, and other EFM growth. In this paper, we are mainly interested in spillovers originating from EM7, and we include EM7 growth in the VAR to reflect that. Growth in other EFM reflects the spillover destination in the model. We include G7 growth in the model to control for growth in the major advanced economies while calculating spillovers from EM7. This also allows us to examine spillovers from the EM7 to the G7, and also spillovers from the G7 to other economies. The latter serves as a baseline against which we compare the size of spillovers originating from EM7. The U.S. interest rate (the yield on 10-year U.S. treasury bills) and the EMBI serve as proxies for global financial conditions. Since the importance of oil prices for economic activity is well established in the literature, we include oil prices as an additional control in the model. In sum, the set of variables included in the VAR describes a standard small open economy DSGE model that characterizes most of the EFMs included in the sample.

The ordering of the variables in the VAR is based on the presumed exogeneity, or predetermination, of variables where more exogenous variables are ordered first. ${ }^{7}$ For instance, it assumes

\footnotetext{
${ }^{7}$ There are alternative identification schemes used in the literature. For instance, Eickmeier (2007) uses sign restrictions to study spillovers between the United States and Germany. Such approaches generally require a much larger set of variables than the one used in this paper and are particularly useful for providing a structural inter-
} 
that G7 growth is relatively exogenous to EM7 growth: a reasonable assumption given their relative economic size. This ordering implies that G7 growth shocks affect EM7 growth within the same quarter, whereas shocks to EM7 growth can affect G7 growth only with a lag of at least one quarter. $^{8}$ Using a similar argument, we order EM7 growth before growth in other EFM. Global financial conditions are assumed to be relatively exogenous to EM7, and hence U.S. interest rates and EMBI are ordered before EM7 growth. By ordering oil price after EM7 growth, we implicitly assume that oil prices are relatively endogenous to EM7 growth. This is consistent with the fact that the EM7, in particular China, are a major source of demand for key commodities including oil and hence, a growth increase in these economies, by increasing demand, can endogenously result in an increase in the price of oil and other commodities.

Given the limited sample period used in this paper (2000Q1-2015Q2), we estimate the model using Bayesian techniques following Litterman (1986). More precisely, we impose the prior that longer lags are more likely to be close to zero than shorter lags. In addition, we impose the prior that own lags of a variable are more important determinant of that variable than lags of other variables in the model. This specification helps improve precision of model estimates by addressing the over-parameterization problem often encountered in estimating VAR models with short time series. Inferences are made using 2000 Monte Carlo draws. We use a lag length of four quarters, which is standard for VAR models estimated with quarterly data.

To estimate growth spillovers from each of the individual EM7 economies, the VAR model above is re-estimated by replacing aggregate EM7 with the individual EM7 economy in question as the spillover source, one at a time. To control for any effects that the rest of the EM7 may have on the spillover destination economies, this version of the model includes aggregate growth in the rest of EM7. For instance, to obtain growth spillovers from Brazil, we estimate a model that includes Brazil growth (spillover source) while controlling for aggregate growth in EM7 excluding Brazil. This would guard against any potential bias in spillover estimates from Brazil if spillovers from the rest of the EM7 (e.g. China) were significant. Given their relative economic size, we order Brazil growth after growth in EM7 excluding Brazil, while preserving the ordering among the rest of the variables as before. Spillovers from the other EM7 economies are estimated, one at a time, following a similar procedure.

An important consideration here is the ordering of oil prices. While oil prices, arguably, are relatively endogenous to growth in some of EM7 economies notably China and India which justifies ordering oil prices after growth in these EM7 economies, it is not obvious this is the case for the rest of EM7 (e.g. Russia, Indonesia). However, to maintain consistency and to ensure that our results are not driven by differences in the ordering of oil prices, we retain the same ordering of oil prices while measuring spillovers from each of the EM7.

Country model. While the aggregate model provides estimates of spillovers to other EFM as a group, we use the country model to estimate spillovers to individual EFM economies. As mentioned

pretation of growth shocks, for instance whether they are supply-driven or demand-driven as in Eickmeier (2007). Given data limitations, a detailed examination of the sources of the growth shock and its implications goes beyond the scope of this paper.

${ }^{8}$ The identification of exogenous growth shocks is possible but less satisfactory with annual data. For instance, with annual data, one would assume that variables ordered last only affect those up the order with a lag of 1 year (e.g. EM7 growth shocks affecting G7 growth) which precludes, by construction, any spillover effects in the immediate periods following the shock. Thus, the spillover analysis in this paper is limited to those economies for which quarterly data is available. 
earlier, the model is estimated for each EFM as a spillover destination, one at a time. Thus, to estimate spillovers from EM7 as a group to each EFM, we include the following variables in the VAR, in this order: G7 growth, EMBI, EM7 growth (spillover source), trade-weighted commodity prices, EFM growth (spillover destination), and EFM real effective exchange rate. The ordering closely follows the aggregate model. Ordering real effective exchange rates last is standard in the literature (e.g. Ilzetzki, Mendoza, and Vegh 2013).

Since the country model is estimated for each spillover destination, we can include countryspecific variables which are tailored to that particular spillover destination - a strategy not available in the aggregate models. Thus, the country model includes trade-weighted commodity prices (instead of oil prices as in the aggregate model) and real effective exchange rates (not available for an aggregate country group). Including exchange rates in the model is consistent with small economy DSGE models such as Galí and Monacelli (2005) and Lubik and Schorfheide (2007). The weights are the average share of exports during 2007-14 of each commodity in the commodity export basket of the spillover destination country in question.

Having a larger set of variables in the country model, however, would result in a loss of degrees of freedom. Thus, for the sake of model parsimony, the country model includes only EMBI as a proxy for global financing conditions and leaves out the U.S. interest rates. Our main results are, however, robust to including only U.S. interest rates as a proxy for global financial conditions, or including both EMBI and U.S. rates. As in the case of the aggregate model, spillovers from individual EM7, as spillover source, are estimated by including the EM7 economy in question while controlling for aggregate growth in the rest of EM7, one at a time.

\subsection{Database}

The estimation uses a balanced panel of quarterly observations for 30 economies between 2000Q1 and 2015Q2 (see Table A1 in the Supplementary Appendix). Real GDP for some of these economies is based on the quarterly database in Ilzetzki, Mendoza, and Vegh (2013) which is extended to 2015Q2 using the OECD Quarterly National Accounts and Haver Analytics. Real GDP data for the remainder of the economies are sourced from the OECD Quarterly National Accounts and Haver Analytics. Real effective exchange rates are the narrow (wherever available) and the broad indices from the Bank for International Settlements (BIS) supplemented with the Bruegel database. The EMBI spread series is taken from J.P. Morgan. The U.S. long-term interest rate is the 10year generic government yields from Bloomberg. Nominal oil prices are obtained from the World Bank Pink Sheet and deflated using seasonally adjusted U.S. CPI series from Haver Analytics. A balanced panel of the GDP series and the EMBI is available from 1998, but we start the sample in 2000 to avoid the immediate periods following the Asian crisis of 1997 and the Russian crisis of 1998. Table A2 in the Supplementary Appendix provides more details of the variables used in this paper.

The trade-weighted commodity prices for each EFM are constructed as follows: nominal monthly prices of 35 commodities are obtained from the World Bank pink sheet. As in the case of oil prices, these nominal commodity prices are deflated by the U.S. CPI. The resulting real prices are converted into indices by setting January 2010 as 100 . Then, the monthly indices are converted into quarterly indices by taking averages across the months in a given quarter. Country-specific trade weights are then applied to these real quarterly commodity price indices to yield a trade-weighted real commodity price index for each country. For a given country, the trade weights are the average 
share of exports of each commodity in the total commodity export basket during the period 2007$2014 .{ }^{9}$ Commodity exports are defined in terms of SITC 4th revision at 4 digits from the World Integrated Trade Solution (WITS) database.

While estimating the model, some of the data are transformed to yield stationary series. Real GDP, oil and commodity prices, and real effective exchange rates, originally in levels, are converted into quarter-on-quarter growth rates. Any residual linear trends in those growth rates are removed. During the sample period used in this paper, the U.S. interest rate and the EMBI exhibit a downward trend. We use first differences of these two series. The aggregate model uses aggregate GDP growth rates for various country groups. Those are calculated as the GDP weighted growth rates of all the countries in a given group. The GDP weights are calculated using the annual current GDP (in US\$) series from the IMF's World Economic Outlook (October 2016) database.

\section{Results}

We present two main sets of results. First, we discuss growth spillovers from aggregate EM7 and compare those with spillovers originating from the G7. Second, we analyze spillovers from each of the individual EM7 to gauge the relative importance of these economies as a source of spillovers.

\subsection{Spillovers from EM7}

We begin by presenting growth spillovers from EM7 using the aggregate model that features aggregate EM7 as the spillover source. Spillovers are analyzed in two different dimensions. First, we show how an exogenous growth shock in EM7 spills over to other economies using impulse responses. We also calculate impulse responses due to a growth shock in G7 to assess the relative size of spillovers from EM7. Second, we perform variance decompositions that show the relative contributions of growth shocks in EM7 vis-à-vis other shocks in the VAR system in explaining business cycle fluctuations in spillover destinations.

Figure 2 presents the impulse responses of model variables to an exogenous growth shock in EM7 that increases its growth by 1 percentage point on impact. ${ }^{10}$ These are highly persistent shocks as they translate into an increase of about 2.7 percentage points in cumulative terms in EM7 growth at the end of three years. Their effect on growth in other EFM is sizeable on impact and they gain momentum over time, with maximum cumulative effect towards the end of three years. On impact, growth in other EFM rises by about 0.3 percentage point in response to the shock, while the cumulative impact at the end of three years is about 0.9 percentage point. These effects are statistically significant at the 2 standard deviation significance level (corresponding to the 16-84 percent confidence bands) which is often used in the literature.

In contrast, the estimated impact on G7 growth is, on average, modest and statistically insignificant. This is partly by construction since G7 growth, ordered first in the VAR, is assumed to be relatively exogenous to EM7 growth. The weak spillover effect on G7 growth may also reflect their net oil-importing status. As net oil importers, G7 economies tend to suffer from the higher oil prices associated with a rise in EM7 growth (Figure 2E). On balance, global growth - calculated as

\footnotetext{
${ }^{9}$ The trade weights are based on 2007-14 averages rather than the full sample period (2000-2015) because the number of missing observations rises considerably before 2007 and after 2014 .

${ }^{10}$ Throughout this paper, we present impulse responses due to positive growth shocks. Since the VAR model used in the paper is linear, the distinction between positive and negative growth shocks is, however, trivial.
} 
the GDP weighted average of the impulse responses of EM7, other EFM, and G7 growth - could increase by 0.6 percentage point at the three-year horizon. ${ }^{11}$ This finding implies that despite the weak spillover effects on advanced economies, a growth increase in the major emerging markets could aid global growth highlighting the economic size of these economies.

How do the EM7 compare with the G7 as a source of spillover? Spillovers from the G7 (as a proxy for the major advanced economies) are a natural baseline to gauge the size of spillovers originating from the EM7. For this, we compare the impulse responses due to an EM7 growth shock and a G7 growth shock, with the size of the shocks normalized, for comparability, such that EM7 and G7 growth increase by 1 percentage point on impact (Figure 3). Sizeable as they are, spillovers from EM7 growth shocks to other EFM remain somewhat smaller than those originating from G7 at all horizons. ${ }^{12}$ For instance, at the end of three years, an increase in G7 growth would raise growth in other EFM by about 0.5 percentage point more than a similarly sized growth increase in EM7. The global impact of spillovers from EM7 is significantly smaller than that from the G7: global growth would increase by about 1.4 percentage points more due to the G7 growth shock than the EM7 growth shock. In other words, growth in other emerging and frontier markets, and the global economy would increase by one-half to three times more due to a similarly sized increase in G7 growth. The larger role of G7 as a source of spillover is corroborated by the variance decomposition - an exercise that factors in the historical size of growth shocks in EM7 and G7. Over the sample period, G7 growth shocks on average explain about 38 and 81 percent of the variation of growth in other EFM and the world economy respectively at the three-year horizon, compared with just 8 and 18 percent explained by EM7 growth shocks (Figure 4).

Stronger spillovers from G7 countries reflect their larger economic size. While the EM7 account for about a quarter of global GDP at market rates, G7 countries account for almost half of global GDP. In addition, G7 countries account for a larger share of global trade and play a central role in global finance. At end-2014, more than half of global banking assets and liabilities were on G7 country banks' balance sheets. The G7 accounted for one-third of global foreign direct investment flows and almost half of global portfolio investment. Thus, financial flows can quickly transmit shocks originating in G7 economies around the world. These results are consistent with previous work that reports similar findings albeit for specific regions. For instance, growth spillovers from Russia to other economies in the Europe and Central Asia region tend to be smaller than those from the European Union, reflecting stronger ties with the latter (Andrle, Garcia-Saltos, and G. Ho 2013; Obiora 2009).

\subsection{Spillovers from Individual EM7}

We now turn to spillovers from each of the individual EM7 economies. For this, we use the version of the aggregate model that features each EM7 economy as the spillover source rather than EM7 as one group. The model is then estimated for each of the EM7 economies as a spillover source, one at a time.

Figure 5A presents the impulse responses at the three-year horizon which is when the cumulative

\footnotetext{
${ }^{11}$ The groups of countries (G7, EM7, and other EFM) constitute about 84 percent of global GDP at market exchange rates in 2014.

${ }^{12}$ Our results are robust when the shock sizes are re-calibrated such that EM7 and G7 growth increase by their respective 1 standard deviation on impact (Figure A2 in the Supplementary Appendix). This calibration scheme would better reflect shock sizes that have historically characterized EM7 and G7 growth.
} 
spillover effects are generally the largest. ${ }^{13}$ As before, for comparability, the shock size is normalized such that growth in each of the EM7 economies increases by 1 percentage point on impact. As the figure shows, the magnitude of spillovers varies across the EM7 economies. The increase in growth in China could raise growth in other EFM by about 0.5 percentage point whereas a similar shock in Russia and India would raise growth in other EFM by about 0.2-0.3 percentage point only. Spillovers from a growth shock in the rest of the EM7 economies - Brazil, Mexico, Indonesia, and Turkey - to other EFM are much smaller and/or statistically insignificant.

Beyond this aggregate impact, we also evaluate the spillover effects of the EM7 on individual EFM economies. For this, we use the country model where we estimate spillovers to each of the individual EFM economies (spillover destinations). Figure 5B summarizes the impulse responses of growth in other EFM economies due to a growth shock in each of the EM7 economies respectively. It reports the cross-sectional average response among the other EFM (spillover destinations) and the corresponding cross-sectional 20-80 percentile range. As the figure shows, an increase in growth in China permeates globally and affects growth in other emerging and frontier markets around the world. ${ }^{14}$ The impulse responses at the 3 -year horizon due to a 1 percentage point increase in China's growth are statistically significant for 13 (8) out of 14 other EFM economies at the 1 standard deviation (2 standard deviations) significance level. ${ }^{15}$ The spillover effects of a shock to growth in Russia are smaller; growth shocks in the rest of the EM7 economies have negligible effects on other EFM economies. Most of these spillover effects are also statistically insignificant.

A robust result from both the aggregate and the country models is that spillovers from growth fluctuations in China are the largest among the major emerging markets, while spillovers originating from Russia, though smaller than China, are non-trivial. The dominant role of China as a spillover source reflects its size and integration. In current dollar terms, China's economy is more than four times the size of the next-largest EM7 economy (Brazil); its imports are six times the size of those of Russia; and its demand for primary energy and metals is four to ten times the size of that of India. These observations explain why growth spillovers from China are the largest among the EM7. Spillovers from Russia reflect its impact on neighboring economies in Europe and Central Asia. Negligible spillovers from the rest of the EM7 economies may reflect their limited integration and/or smaller economic size.

How would spillovers from an increase in growth in just China compare with those from a synchronous increase in growth in EM7? This is a relevant question given that cyclical fluctuations in emerging markets are often highly synchronized (Claessens, Kose and Terrones 2012). ${ }^{16}$ For this, we compare the spillover results from two different versions of the aggregate model: one that features aggregate EM7 as the spillover source and another that features China as the spillover source to aggregate growth in EFM. A synchronous EM7 growth increase is defined as one in which EM7 growth increases by the same amount as an isolated increase in China's growth, which we

\footnotetext{
${ }^{13}$ Our results are generally robust when the impulse responses are analyzed at shorter horizons. For instance, Figure A4 in the Supplementary Appendix presents results at the two-year horizon.

${ }^{14}$ Given the important role of China for global commodity demand, spillover effects from China could be more pronounced for commodity exporters than importers (Ahuja and Nabar 2012; Inoue, Kaya, and Ohshige 2015). Our results suggest that this is indeed the case. See Figure A1 in the Supplementary Appendix.

${ }^{15}$ Due to unavailability of trade-weighted commodity prices data for Phillipines, the country model is not estimated for this country.

${ }^{16}$ This has been the case in the recent growth slowdown as well since much of it has been synchronous and not limited to China alone (Didier et al. 2015).
} 
assume to be a 1 percentage point increase on impact. ${ }^{17}$ In a synchronous increase in growth, activity in China's trading partners that are also closely linked to their regional EM7 would be doubly hit. Thus, growth in other EFM could increase by around 0.2 percentage point more, over three years, in a synchronous increase in growth in EM7 than in an isolated increase in China's growth (Figure 6). The upshot here is that even though spillovers from China are sizeable, a synchronous acceleration in growth in EM7 would have considerably larger spillover effects than just an increase in China's growth alone.

\section{Robustness}

We consider a wide range of exercises to check the robustness of our headline findings. To begin with, we focus on spillovers from EM7 as a group. We compare the results from the baseline model with the following specifications. First, we estimate those spillovers by including a dummy for the global financial crisis of 2008-09. Second, we study spillovers when oil prices are included as an exogenous variable rather than an endogenous variable as in the baseline model. In this alternative specification, oil prices, by construction, do not endogenously respond to an increase in growth in EM7. By comparing the spillover results from this specification with those from the baseline model, we can gauge the extent to which oil prices endogenously transmit EM7 growth shocks across borders. Third, we examine spillovers when the model is estimated using industrial production instead of GDP.

Fourth, we check the consistency between the baseline and the country models. For this, the spillover estimates obtained from the country models for each of the other EFM economies (spillover destinations) are aggregated using their respective GDP shares, which is then compared with the spillover estimate for other EFM (as an aggregate) obtained from the baseline model. Fifth, we estimate a factor-augmented version of the baseline model by replacing aggregate growth in each of the country groups, i.e. G7, EM7, and other EFM, with the estimated common factor of growth in individual economies in each group respectively. For instance, we replace aggregate G7 growth with the common factor of growth in individual G7 economies. ${ }^{18}$ Since the common factors are not a-priori dependent on GDP weights, they serve as an alternative way to represent "aggregate" growth dynamics in each of the country groups. Sixth, we consider BRICS (Brazil, Russia, India, China, and South Africa) as an alternative group to characterize the large emerging markets, and compare our headline result (i.e. spillovers from EM7) with spillover estimates from BRICS. ${ }^{19}$ Finally, we add some other countries to our baseline other EFM group: Hong Kong SAR, China; Singapore; and Korea Republic.

Table 1 presents the results. We report the median responses of growth in other EFM to a 1 percentage point increase in EM7 growth along with the 16-84 percent confidence bands. As

\footnotetext{
${ }^{17}$ Our results are robust when the shock sizes are re-calibrated such that EM7 and China's growth increase by their respective 1 standard deviation on impact (Figure A3 in the Supplementary Appendix).

${ }^{18}$ The common factors are estimated as the first principal component of growth in individual economies in each group. As is standard in principal component analysis, the absolute scale of the estimated factors is unidentified. Hence, the point estimates of the spillovers are less comparable with the baseline results. We use this specification primarily to check the direction and statistical significance of spillover estimates.

${ }^{19}$ Among EM economies, South Africa is ranked 13th in terms of GDP size in 2015 and hence, does not feature in our EM7. Since South Africa, as a member of BRICS, is a spillover source in this specification, the spillover destination is taken to be other EFM minus South Africa. For robustness, we also consider other alternative groups as the spillover source. For instance, we analyze spillovers from the group "EM7 plus South Africa". We also consider other alternative groups by adding each of Hong Kong SAR China, Singapore, and Korea Republic to EM7. Our headline results are robust to these alternative groupings (Table A3).
} 
expected, when the global financial crisis is controlled for, the point estimates of spillovers from EM7 to other EFM are slightly smaller than what the baseline model suggests. Spillovers in the baseline model are marginally smaller than those in the alternative model specification assuming exogenous oil prices. This suggests that an increase in oil prices induced by the increase in growth in EM7, as in the baseline model, offsets some of the favorable spillover effects to other EFM given the latter's net-oil importing status. The point estimates of spillovers from BRICS are also insignificantly different from those from EM7 given the overlapping confidence bands. While the point estimates of spillovers from the rest of the alternative model specifications deviate somewhat from those of the baseline model, those deviations are statistically insignificant as well. All in all, a robust finding from all these specifications is that spillover estimates are sizeable and statistically significant. We obtain very similar results when the baseline model is estimated by including VIX instead of EMBI. Our headline results are also robust to the inclusion or exclusion of U.S. interest rates.

We also check the robustness of the spillover estimates from individual EM7. The baseline model measures spillovers from each of the EM7 while controlling for the rest of the EM7. This guards against any potential bias in spillover estimates from, say Brazil, if spillovers from the rest of the EM7 (e.g. China) were significant. For robustness, we measure spillovers from each of the EM7 without controlling for the rest of EM7.

Figure 7A presents the results from the aggregate model. The point estimates are quite close to the baseline specification (Figure 5A). More importantly, our headline result remains that China dominates as a spillover source among the EM7. In addition, as in the baseline specification, spillovers from Russia, while smaller than China's, are non-trivial while spillovers from the rest of the EM7 economies are negligible and/or statistically insignificant. Figures 7B presents the results from the alternative specification of the country model. These are in line with the baseline results (Figure 5B) as well. In sum, our earlier finding that among the EM7, spillovers from China are the largest and have a global outreach is robust to changes in the model specification.

\section{Conclusion}

We provide empirical estimates of spillovers from the largest seven emerging market (EM7) economies using a parsimonious VAR model. Our paper adds to the existing literature on spillovers from the major emerging markets in several dimensions. First, by using a large quarterly dataset that includes advanced, emerging, and frontier economies, it assesses the global implications of spillovers from EM7. Second, it examines how spillovers from EM7 compare with those originating from the G7. Third, using a common methodology, it includes a disciplined comparison of spillovers originating from the individual EM7 economies in the context of a model that includes all the major variables that are featured in a standard small open economy DSGE model.

Our results suggest that spillovers from EM7 to other emerging and frontier markets are sizeable: a 1 percentage point increase in EM7 growth can raise growth in other EFM by about 0.9 percentage point in cumulative terms at the end of 3 years. On the contrary, we find that spillovers from EM7 to advanced economies are, on average, modest and statistically insignificant. On balance, global growth could increase by 0.6 percentage point at the three-year horizon reflecting the economic size of emerging markets, in particular EM7. Among the EM7 economies, spillovers from China are the largest and permeate globally. Sizeable as they are, spillovers from EM7 are somewhat smaller than those originating from G7 economies. 
By providing a set of baseline stylized facts, these results constitute ground work for the specification, calibration and evaluation of DSGE models that analyze cyclical spillovers from advanced and emerging economies. Understanding the magnitude and channels of spillovers from EM7 is a fertile ground for future theoretical and empirical research. Future work can usefully consider the roles played by common shocks (e.g. common monetary and fiscal policy shocks) and the importance of trade and financial linkages in transmitting cross-border spillovers from EM7 and G7. 


\section{References}

[1] Ahuja, A., and M. Nabar. 2012. "Investment-Led Growth in China: Global Spillovers." Working Paper 12/267, International Monetary Fund, Washington, DC.

[2] Alturki, F., J. Espinosa-Bowen, and N. Ilahi. 2009. "How Russia Affects the Neighborhood: Trade, Finance, and Remittance Channels." Working Paper 09/277, International Monetary Fund, Washington, DC.

[3] Ambler, S., E. Cardia, C. Zimmermann. 2002. "International Transmission of the Business Cycle in a Multi-sector Model." European Economic Review 46 (2): 273-300.

[4] Andrle, M., R. Garcia-Saltos, and G. Ho. 2013. "The Role of Domestic and External Shocks in Poland: Results from an Agnostic Estimation Procedure." Working Paper 13/220, International Monetary Fund, Washington, DC.

[5] Canova. F. 2005. "The Transmission of US Shocks to Latin America." Journal of Applied Econometrics 20 (2): 229-251

[6] Canova, F., and J. Marrinan. 1998. "Sources and Propagation of International Output Cycles: Common Shocks or Transmission?" Journal of International Economics 46 (1): 133-166.

[7] Claessens, S., M. A. Kose, M. E. Terrones. 2012. "How do Business and Financial Cycles Interact?" Journal of International Economics 87(1): 178-190.

[8] Comin, D., N. Loayza, F. Pasha, and L. Serven. 2014. "Medium Term Business Cycles in Developing Countries." American Economic Journal: Macroeconomics, 6(4): 209-45.

[9] De Walque, G., F. Smets, and R. Wouters. 2005. "An Estimated two-country DSGE Model for the Euro Area and the US Economy." National Bank of Belgium, Mimeo, European Central Bank.

[10] Didier, T., M.A. Kose, F. Ohnsorge, and L. Ye. 2015. "Slowdown in Emerging Markets: Rough Patch or Prolonged Weakness?" Policy Research Note 4, World Bank, Washington, DC.

[11] Diebold, F. X. and K. Yilmaz. 2015. "Financial and Macroeconomic Connectedness: A Network Approach to Measurement and Monitoring." Oxford: Oxford University Press.

[12] Doyle, B., and J. Faust. 2002. "An Investigation of Comovements among the Growth Rates of the G-7 Countries." Federal Reserve Bulletin 427- 437, Board of Governors of the Federal Reserve System, Washington, DC.

[13] Eickmeier, S. 2007. "Business Cycle Transmission from the US to Germany-A Structural Factor Approach." European Economic Review 51 (3): 521-551.

[14] Frankel, J., and A. Rose. 1998. "The Endogeneity of the Optimum Currency Area Criteria." The Economic Journal 108: 1009-1025.

[15] Galí, J. and T. Monacelli. 2005. "Monetary Policy and Exchange Rate Volatility in a Small Open Economy." Review of Economic Studies 72: 707-734.

[16] Gregory, A.W., A. Head, J. Raynauld. 1997. "Measuring World Business Cycles." International Economic Review 38: 667-702. 
[17] Ilzetzki, E., E. G. Mendoza, and C. A. Vegh. 2013. "How Big (Small?) are Fiscal Multipliers?" Journal of Monetary Economics 60 (2): 239-254.

[18] Inoue, T., D. Kaya, and H. Ohshige. 2015. "The Impact of China's Slowdown on the Asia Pacific Region: An Application of the GVAR Model." Policy Research Working Paper 7442, World Bank, Washington, DC.

[19] Kose, M. A. 2002. "Explaining Business Cycles in Small Open Economies: How much do World Prices Matter?"' Journal of International Economics, 56(2): 299-327.

[20] Kose, M. A., C. Otrok, and C. Whiteman. 2003. "International Business Cycles: World, Region, and Country Specific Factors." American Economic Review 93 (4): 1216-1239.

[21] Kose, M. A., and E. Prasad. 2010. "Emerging Markets: Resilience and Growth Amid Global Turmoil." Washington: Brookings Institution Press.

[22] Kose, M. A., E. Prasad, and M. Terrones. 2009. "Does Financial Globalization Promote Risk Sharing?" Journal of Development Economics 89: 258-270.

[23] Litterman, R.B. 1986. "Forecasting with Bayesian Vector Autoregressions-Five Years of Experience." Journal of Business \& Economic Statistics, 4 (1): 25-38.

[24] Lubik, T. and F. Schorfheide. 2007. "Do Central Banks Respond to Exchange Rate Movements? A Structural Investigation." Journal of Monetary Economics 54: 1069-1087.

[25] Magnus, G. 2011. "Uprising: Will Emerging Markets Shape or Shake the World Economy?" Hoboken, New Jersey: John Wiley and Sons.

[26] Neumeyer, A. and F. Perri. 2005. "Business Cycles in Emerging Economies: The Role of Interest Rates." Journal of Monetary Economics 52(2): 345-380.

[27] Obiora, K. 2009. "Decoupling from the East toward the West? Analyses of Spillovers to the Baltic countries." IMF Working Paper 09/129. International Monetary Fund, Washington, DC.

[28] Sharma, R. 2012. "Breakout Nations: In Pursuit of the Next Economic Miracles." New York: Norton.

[29] Stock, J., and M. Watson. 2005. "Understanding Changes in International Business Cycle Dynamics." Journal of the European Economic Association 3 (5): 968-1006. 
Figure 1: Global importance of Emerging Markets and EM7 A. EM share of Global Output

\section{Percent}

80

60

40

20

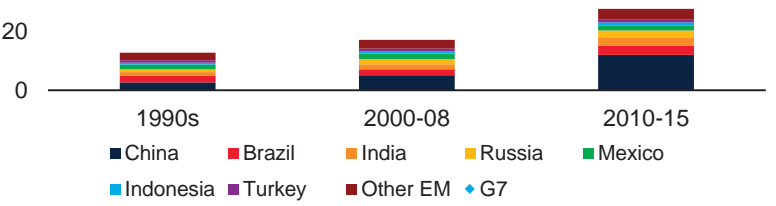

C. Global integration of EM and AM

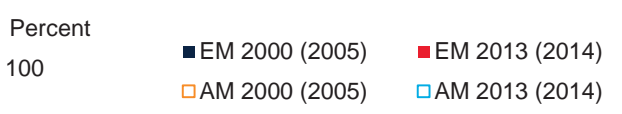

80

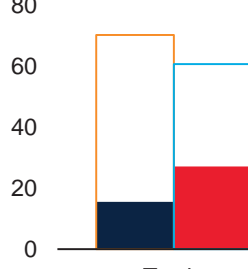

Trade

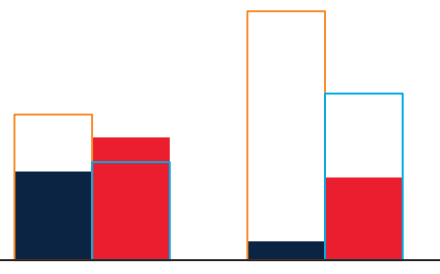

Remittances

FDI flows
B. EM contribution to global growth

Percentage point

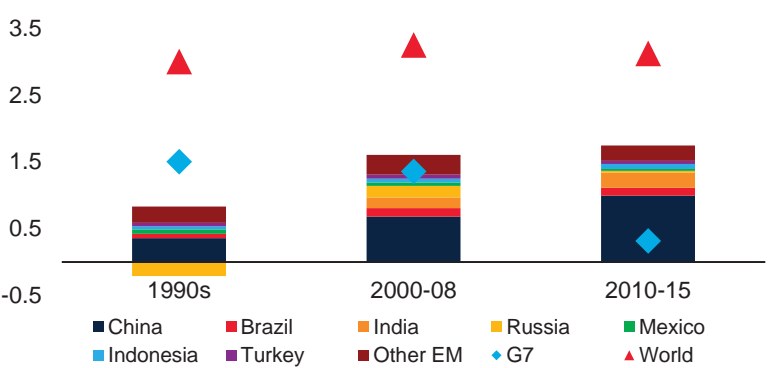

D. Global integration of EM7 and G7

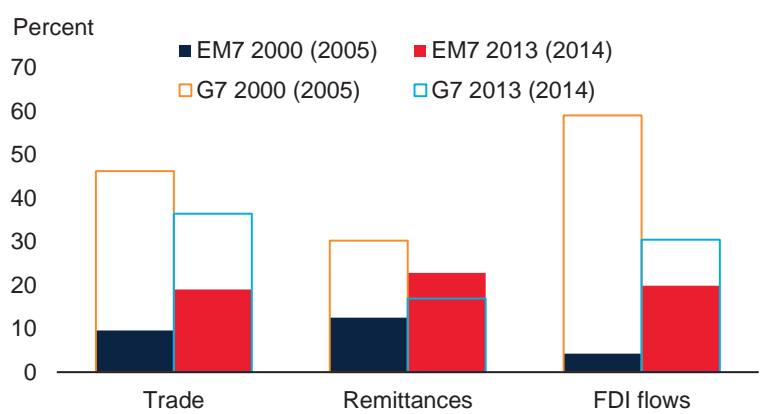

Note: EM stands for emerging markets; EM7 for the group of 7 countries: Brazil, China, India, Indonesia, Mexico, Russia, and Turkey; G7 stands for the group of 7 countries: Canada, France, Germany, Italy, Japan, United Kingdom, and United States; AM for advanced markets.

C.D. Due to data constraints, global trade (exports plus imports) from 2000 and 2013; remittances (inflows plus outflows) data from 2000 and 2013 ; foreign direct investment (FDI) flows (inflows plus outflows) from 2000 and 2014; and international investment position (IIP, including direct investment, portfolio investment, financial derivatives, and other investment assets and liabilities) from 2005 and 2013. 
Figure 2: Impulse responses due to a 1 percentage point increase in EM7 growth
A. Other EFM
B. G7

Percentage point

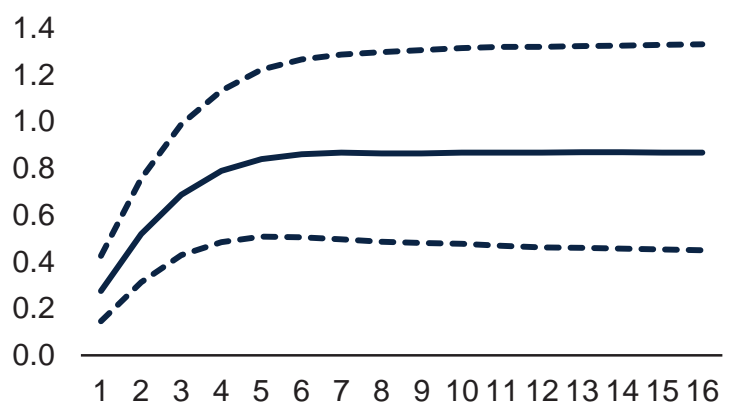

\section{Global economy}

Percentage point

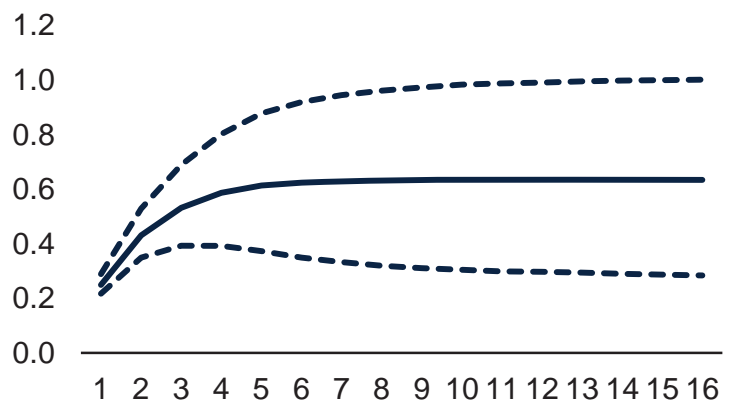

\section{E. Oil prices}

Percentage point

25.0

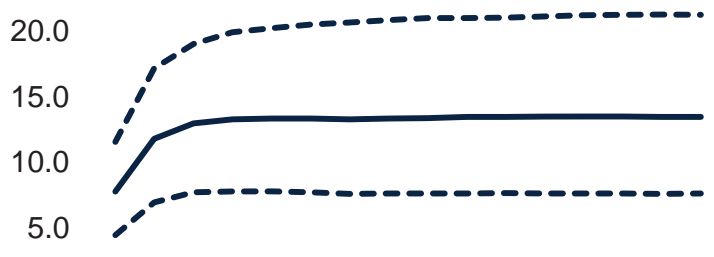

0.0

$122 \quad 3 \quad 4 \quad 5 \quad 6 \quad 7 \quad 8 \quad 910111213141516$
Percentage point

0.3

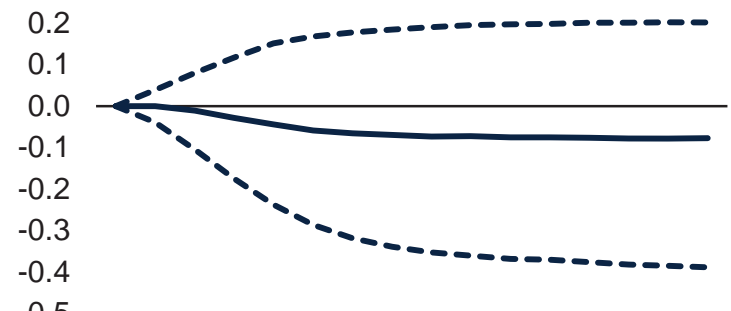

$122 \quad 3 \quad 4 \quad 5 \quad 6 \quad 7 \quad 8 \quad 910111213141516$

D. EM7

Percentage point

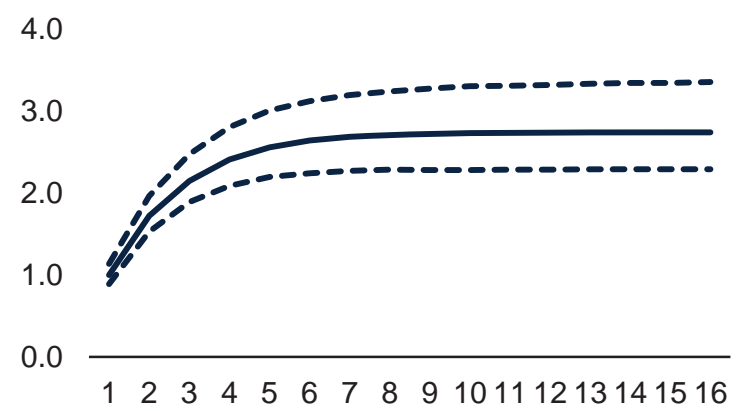

Note: Other EFM refers to the group of emerging and frontier markets excluding EM7. The graphs show the cumulated impulse responses at different horizons due to a 1 percentage point increase on impact in EM7 growth. Global is GDPweighted average of the response of EM7, other EFM, and G7 responses. Solid lines represent medians, and dotted lines represent 16-84 percent confidence bands. 
Figure 3: Impulse responses due to a 1 percentage point increase in G7 and EM7 growth A. Other EFM

Percentage point

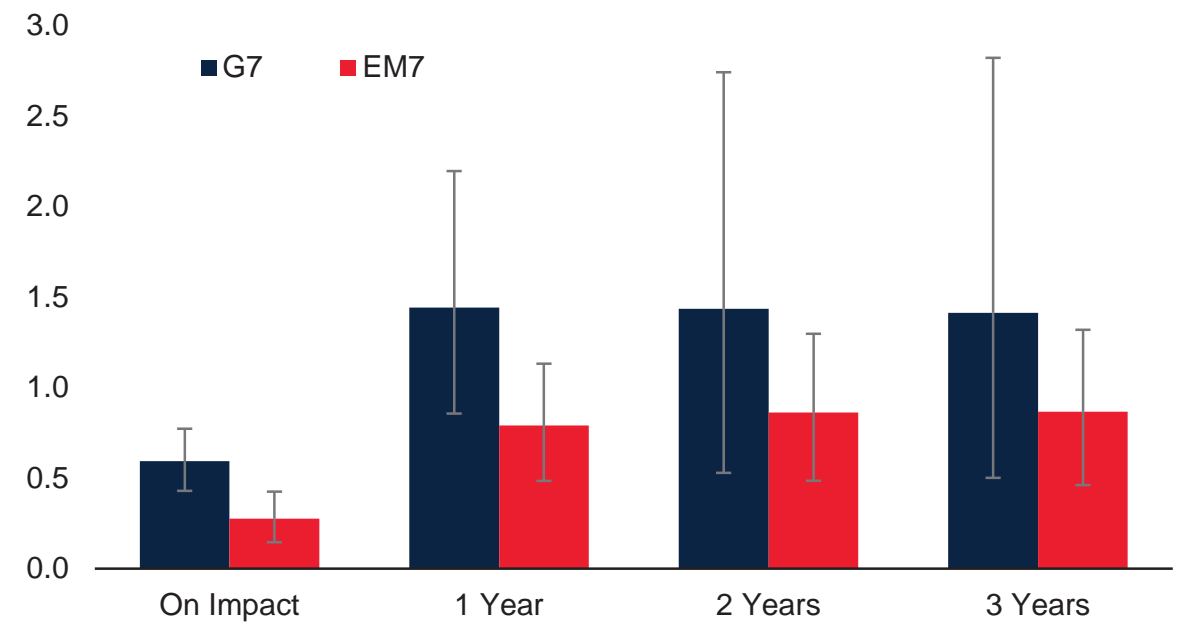

B. Global economy

Percentage point

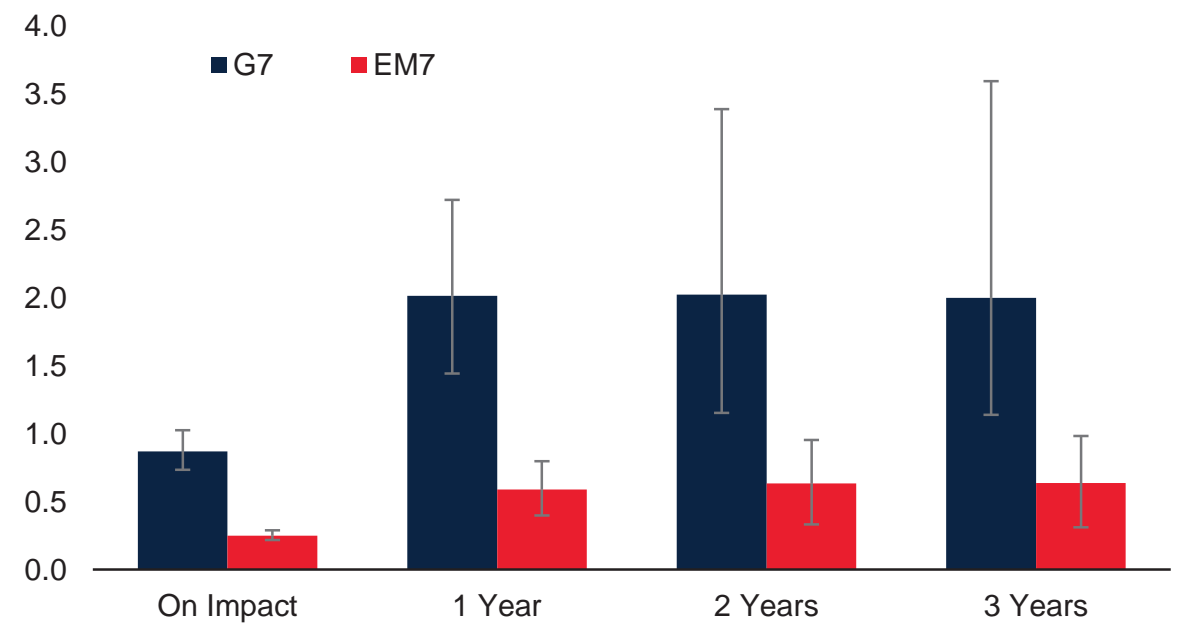

Note: The graphs show the cumulated impulse responses of growth in other EFM, at different horizons, due to a 1 percentage point increase on impact in G7 and EM7 growth. The impulse response of the global economy is calculated as the GDP-weighted average of the responses of G7, EM7, and other EFM. Solid bars represent medians, and error bars represent 16-84 percent confidence bands. 
Figure 4: Variance share explained by G7 and EM7 growth shocks

\section{A. Other EFM}

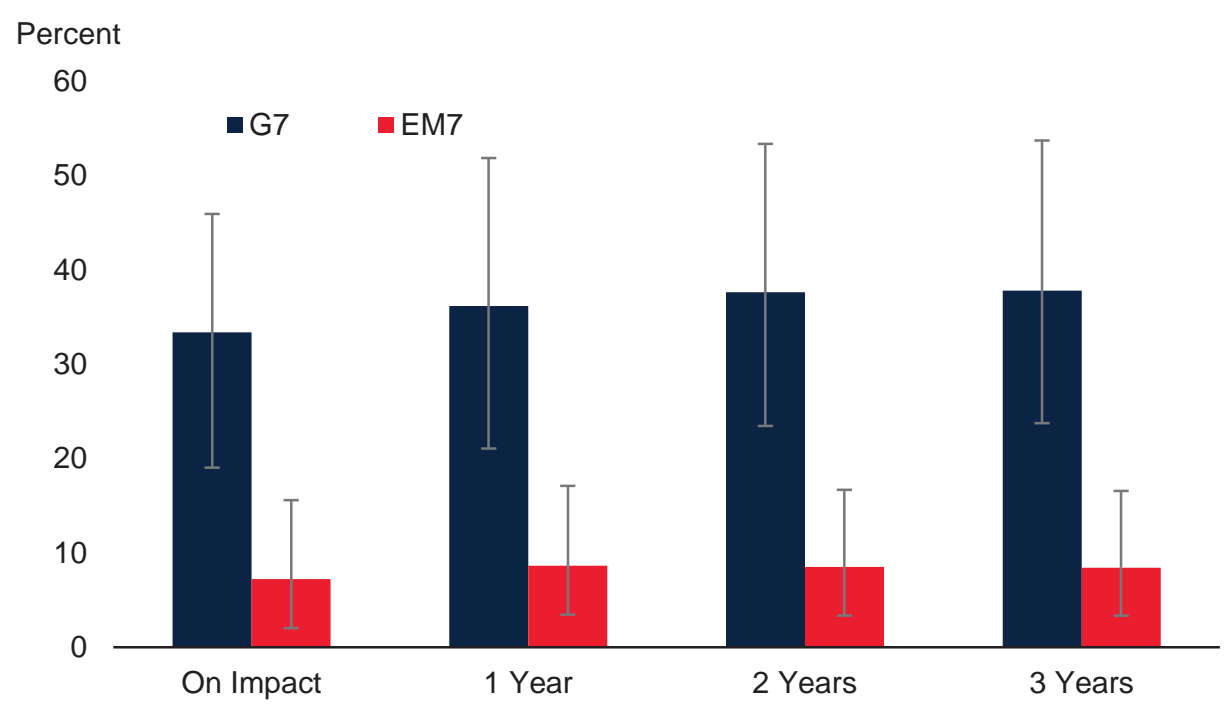

\section{B. Global economy}

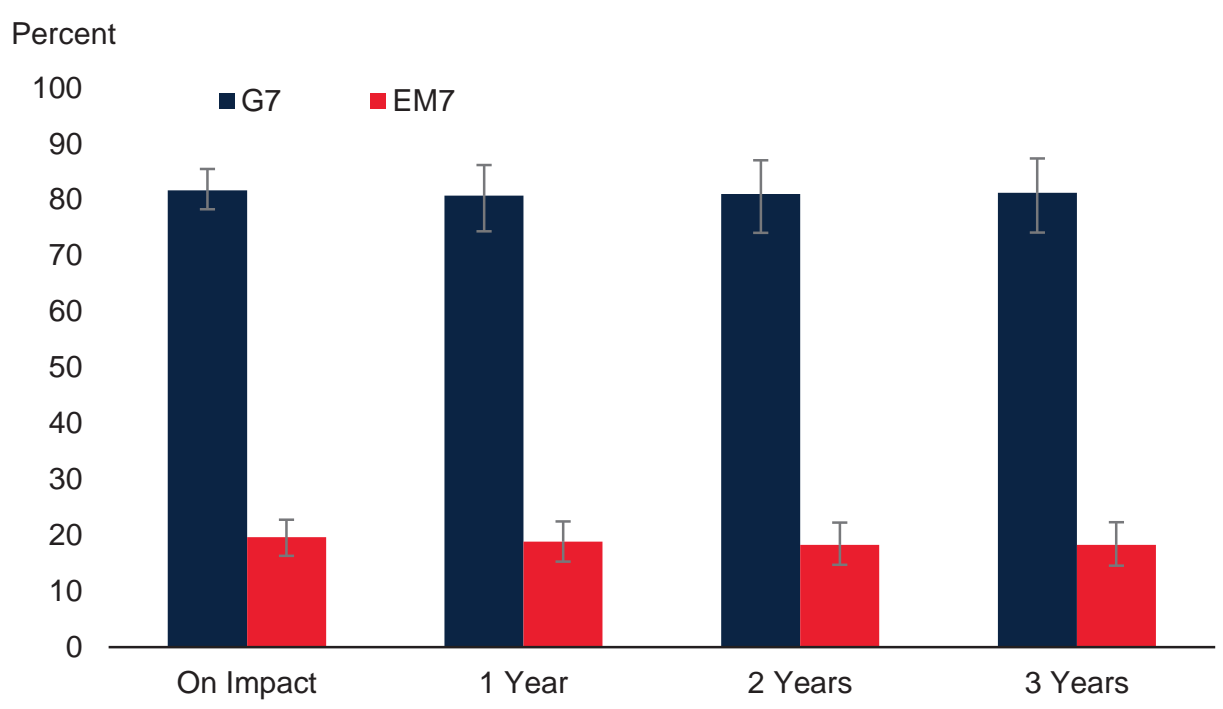

Note: The graphs show the variance share of growth in other EFM (Figure A) and the global economy (Figure B), at different horizons, explained by shocks to G7 and EM7 growth. The variance share of the global economy is calculated as the GDP-weighted average of the variance shares of G7, EM7, and other EFM. Solid bars represent medians, and error bars represent 16-84 percent confidence bands. 
Figure 5: Impulse responses due to a 1 percentage point increase in growth in individual EM7

A. Aggregate spillovers

Percentage point

1.2

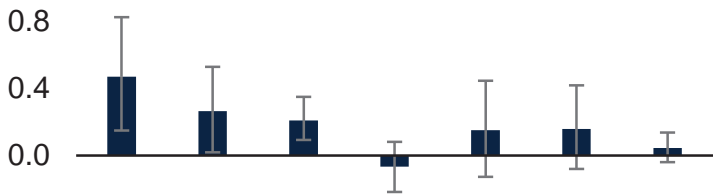

$-0.4$

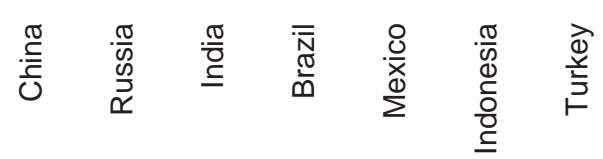

\section{B. Country spillovers}

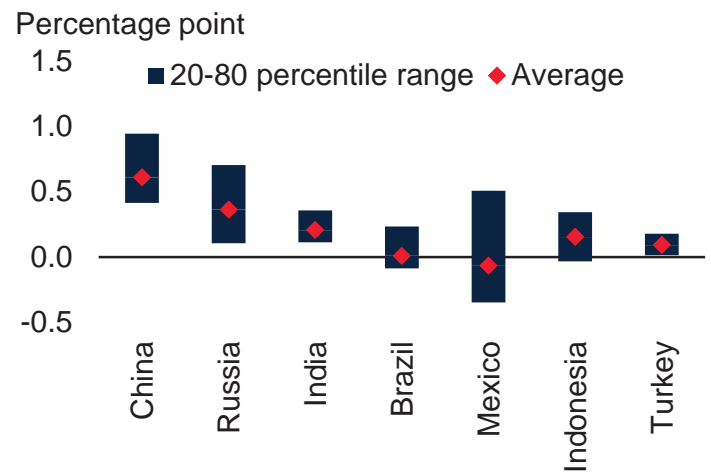

Note:

A. The graph shows cumulated impulse responses of growth in other EFM at the end of three years due to a 1 percentage point increase on impact in each of the EM7 growth. These results are from the aggregate VAR model. Solid bars represent medians, and the error bands represent 16-84 percent confidence bands.

$\mathrm{B}$. The graph shows the cumulated impulse responses at the end of three years due to a 1 percentage point increase on impact in each of the EM7 growth. These results are from the country models. For each spillover source country, the bar denotes the 20-80 percentile range of the responses of other EFM economies and the red diamond denotes the cross-sectional average response. 
Figure 6: Impulse responses due to a 1 percentage point increase in EM7 and China's growth

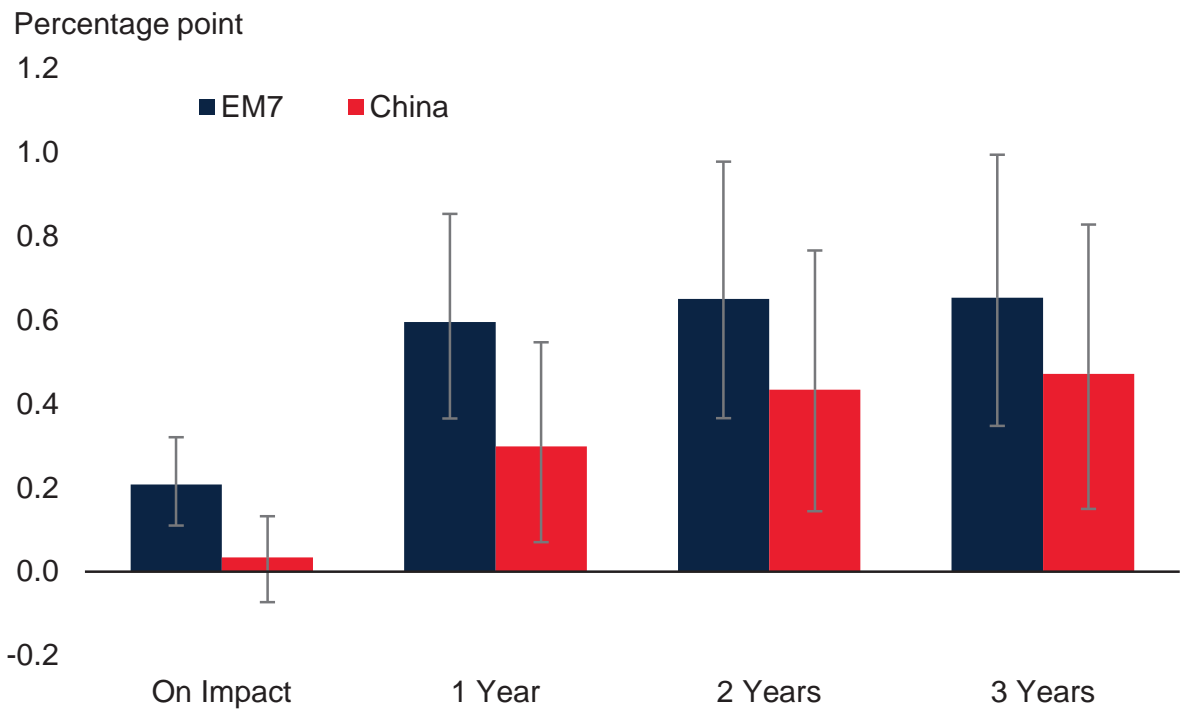

Note: The graphs show the cumulated impulse responses of growth in other EFM, at different horizons, due to a 1 percentage point increase on impact in EM7 and China's growth. Solid bars represent medians, and error bars represent 16-84 percent confidence bands. 
Figure 7: Robustness checks: Spillovers from individual EM7

A. Aggregate spillovers

Percentage point

1.2

0.8

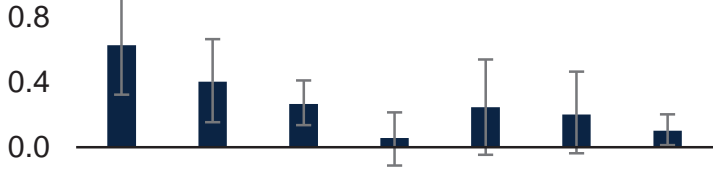

$-0.4$

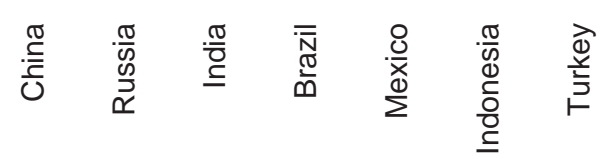

B. Country spillovers

Percentage point

$1.5 \quad$ 20-80 percentile range $\bullet$ Average

1.0

0.5

0.0

$-0.5$

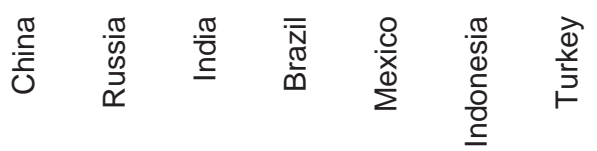

Note:

A. The graph shows cumulated impulse responses at the end of three years due to a 1 percentage point increase on impact in each of the EM7 growth. These results are from the alternative specification of the aggregate model where growth in the rest of EM7 is not controlled for while measuring spillovers from each EM7.

$\mathrm{B}$. The graph shows the cumulated impulse responses at the end of three years due to a 1 percentage point increase on impact in each of the EM7 growth. These results are from the alternative specification of the country models where growth in the rest of EM7 is not controlled for while measuring spillovers from each EM7. For each spillover source country, the bar denotes the cross-sectional 20-80 percentile range of the responses of other EFM economies and the red diamond denotes the cross-sectional average response. 
Table 1: Robustness checks: Spillovers from EM7

\begin{tabular}{|c|c|c|c|c|}
\hline & On impact & 1 year & 2 years & 3 years \\
\hline Aggregate model (bas eline) & $\begin{array}{c}\mathbf{0 . 2 8} \\
{[0.15 \quad 0.43]}\end{array}$ & $\begin{array}{c}\mathbf{0 . 7 9} \\
{[0.48 \text { 1.13] }} \\
\end{array}$ & $\begin{array}{c}\mathbf{0 . 8 6} \\
{[0.491 .3]} \\
\end{array}$ & $\begin{array}{c}\mathbf{0 . 8 7} \\
{\left[\begin{array}{ll}0.46 & 1.32\end{array}\right]} \\
\end{array}$ \\
\hline Global financial crisis dummy & $\begin{array}{c}\mathbf{0 . 2 6} \\
{\left[\begin{array}{ll}0.14 & 0.4\end{array}\right]}\end{array}$ & $\begin{array}{c}\mathbf{0 . 7 8} \\
{\left[\begin{array}{ll}0.52 & 1.07\end{array}\right]} \\
\end{array}$ & $\begin{array}{c}\mathbf{0 . 8 4} \\
{\left[\begin{array}{ll}0.53 & 1.18\end{array}\right]} \\
\end{array}$ & $\begin{array}{c}\mathbf{0 . 8 5} \\
{\left[\begin{array}{ll}0.54 & 1.19\end{array}\right]} \\
\end{array}$ \\
\hline Controlling for oil prices & $\begin{array}{c}\mathbf{0 . 2 8} \\
{\left[\begin{array}{ll}0.15 & 0.4\end{array}\right]} \\
\end{array}$ & $\begin{array}{c}\mathbf{0 . 8 7} \\
{[0.58 \text { 1.18] }}\end{array}$ & $\begin{array}{c}1.34 \\
{[0.931 .81]}\end{array}$ & 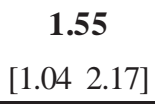 \\
\hline Indus trial production series & $\begin{array}{c}\mathbf{0 . 3 9} \\
{[0.10 .7]}\end{array}$ & $\begin{array}{c}\mathbf{0 . 9 7} \\
{\left[\begin{array}{ll}0.4 & 1.6\end{array}\right]}\end{array}$ & $\begin{array}{c}\mathbf{0 . 9 3} \\
{\left[\begin{array}{ll}0.3 & 1.6\end{array}\right]}\end{array}$ & $\begin{array}{c}\mathbf{0 . 9 3} \\
{\left[\begin{array}{ll}0.3 & 1.6\end{array}\right]}\end{array}$ \\
\hline Country model & 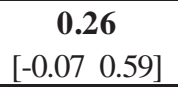 & 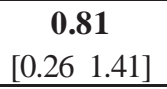 & $\begin{array}{c}\mathbf{0 . 8 8} \\
{[0.23 \text { 1.58] }}\end{array}$ & $\begin{array}{c}\mathbf{0 . 8 9} \\
{[0.24 \quad 1.62]}\end{array}$ \\
\hline Factor-augmented model & $\begin{array}{c}\mathbf{0 . 2 8} \\
{\left[\begin{array}{ll}0.01 & 0.57\end{array}\right]} \\
\end{array}$ & 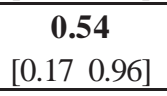 & $\begin{array}{c}\mathbf{0 . 5 2} \\
{[0.10 .94]}\end{array}$ & 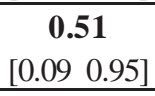 \\
\hline Spillovers from BRICS & $\begin{array}{c}\mathbf{0 . 2 0} \\
{\left[\begin{array}{ll}0.08 & 0.34\end{array}\right]}\end{array}$ & $\left.\begin{array}{c}\mathbf{0 . 6 9} \\
{[0.39} \\
{[0.98}\end{array}\right]$ & $\begin{array}{c}\mathbf{0 . 8 0} \\
{[0.431 .16]}\end{array}$ & $\begin{array}{c}\mathbf{0 . 8 0} \\
{[0.421 .2]}\end{array}$ \\
\hline $\begin{array}{l}\text { Spillovers to other EFM plus Hong Kong, } \\
\text { Singapore, Korea Rep. }\end{array}$ & $\begin{array}{c}\mathbf{0 . 5 9} \\
{[0.430 .75]}\end{array}$ & 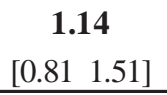 & 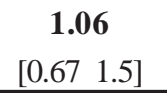 & $\begin{array}{c}1.05 \\
{[0.651 .5]}\end{array}$ \\
\hline
\end{tabular}

Note: The table shows the cumulated impulse responses of growth in other EFM, for different horizons, due to a 1 percentage point increase on impact in EM7 growth. These are from the alternative specifications of the aggregate model. Bolded denote the medians and the numbers in the parentheses are the 16-84 percent confidence bands. Global financial crisis dummy: includes a dummy for the global financial crisis of 2008-09; Controlling for oil prices: oil prices are treated as an exogenous regressor in the model; Industrial production series: estimates are based on industrial production growth; Country model: spillover estimates for the individual EM excluding EM7 economies from the country models are aggregated by GDP weights; Factor-augmented model: estimates are based on the common factor (first principal component) each of G7, EM7, and other EFM economies; Spillovers from BRICS: estimates are based on spillovers from BRICS. The spillover destination in this case is other EFM minus South Africa; Spillovers to other EFM plus Hong Kong, Singapore, Korea Rep.: estimates for alternative definition of spillover destination that includes other EFM and Hong Kong, Singapore, Korea Republic. 


\section{Supplementary Appendix}

How Important are Spillovers from Major Emerging Markets?

Raju Huidrom, M. Ayhan Kose, and Franziska L. Ohnsorge 
Table A1: Country classification

\begin{tabular}{|c|c|c|c|c|c|c|c|c|c|}
\hline \multicolumn{3}{|c|}{ Advanced Markets } & \multicolumn{3}{|c|}{ Emerging Markets } & \multirow{2}{*}{\multicolumn{4}{|c|}{ Frontier Markets }} \\
\hline \multirow{2}{*}{$\begin{array}{r}\text { G7 } \\
\text { Canada* }\end{array}$} & \multicolumn{2}{|c|}{\begin{tabular}{|l|} 
Other Advanced Markets \\
\end{tabular}} & \multirow{2}{*}{\begin{tabular}{|l|} 
EM7 \\
Brazil* $^{*}$
\end{tabular}} & \multicolumn{2}{|c|}{\begin{tabular}{|c|} 
Other Emerging Markets \\
\end{tabular}} & & & & \\
\hline & Australia & Luxembourg & & Chile* & Poland* & Argentina & Ecuador & Kenya & Romania* \\
\hline France* & Austria & Malta & China* & Colombia & Qatar & Azerbaijan & El Salvador & Kuwait & Senegal \\
\hline Germany* & Belgium & Netherlands & India* & Czech Republic* & Saudi Arabia & Bahrain & Gabon & Lebanon & Serbia \\
\hline Italy* & Denmark & Norway & Indonesia* & Egypt & South Africa* & Bangladesh & Georgia & Mauritius & Sri Lanka \\
\hline Japan* & Finland & New Zealand & Mexico* & Hungary* & Thailand* & Bolivia & Ghana & Mongolia & Tunisia \\
\hline United Kingdom* & Greece & Portugal & Russia* & Malaysia* & $\begin{array}{l}\text { United Arab } \\
\text { Emirates }\end{array}$ & Botswana & Guatemala & Namibia & Ukraine \\
\hline \multirow[t]{4}{*}{ United States* } & $\begin{array}{l}\text { Hong Kong SAR, } \\
\text { China }\end{array}$ & Singapore & Turkey* & Morocco & & Bulgaria* & Honduras & Nigeria & Uruguay \\
\hline & Ireland & Spain & & Pakistan & & Costa Rica* & Jamaica & Oman & Venezuela \\
\hline & Iceland & Sweden & & Peru* & & Cote d'Ivoire & Jordan* & Panama & Vietnam \\
\hline & Korea Republic & Switzerland & & Philippines* & & Croatia* & Kazakhstan & Paraguay* & Zambia \\
\hline
\end{tabular}

Note: The table shows the list of countries and their classification. Emerging markets (EM) include economies that currently are, or have been for most of their recent history, middle-income countries with a long established record of access to international financial markets. Frontier markets (FM) include economies that are usually smaller and less developed than EM and, in the view of investors, considerably riskier (although economies undergoing extreme economic or political instability are excluded). Technically, the EM and FM classification in this paper consolidates the ones independently developed by FTSE and S\&P. The Advanced

Markets (AM) category follows the IMF classification. Countries with an asterisk are the ones included in the model estimation. G7 and EM7 represent the major $\mathrm{AM}$ and EM economies respectively. 
Table A2: Database

\begin{tabular}{llll}
\hline \multicolumn{1}{c}{ Variable } & \multicolumn{1}{c}{ Definition } & Frequency & \multicolumn{1}{c}{ Source } \\
\hline Output & Real gross domestic product (GDP) & Quarterly & Ilzetzki, Mendoza, and Vegh (2013), OECD, Haver Analytics \\
Output & Nominal gross domestic product in US\$ (GDP) & Annual & World Economic Outlook (October 2016) \\
EMBI & Emerging market bond index & Quarterly & J.P. Morgan \\
U.S. interest rate & Nominal yield on 10-year government bonds & Quarterly & Bloomberg \\
Oil price & Nominal oil prices & Quarterly & World Bank Pink Sheet \\
Commodity prices & Nominal commodity prices & Quarterly & World Bank Pink Sheet \\
& Commodity exports defined using SITC 4th & & \\
Commodity exports & revision at 4 digits & Annual & World Integrated Trade Solution (WITS) \\
Real effective exchange rate & Real effective exchange rate & Quarterly & BIS, Bruegel datasets \\
U.S. CPI & Consumer price index & Quarterly & Haver Analytics \\
VIX & CBOE volatility index & Quarterly & CBOE \\
\hline
\end{tabular}

Note: The table describes the variables used in the model estimation and their sources.

a The main source for the quarterly series is Ilzetzki, Mendoza, and Vegh (2013). This database which ends around 2008 is extended by splicing from different sources.

b The narrow index wherever available is taken while the remainder uses the broad index. Details are available upon request. 
Table A3: Robustness checks: Spillovers from alternative definitions of large EM

\begin{tabular}{|c|c|c|c|c|}
\hline & On impact & 1 year & 2 years & 3 years \\
\hline Spillovers from EM7 (baseline) & $\begin{array}{c}\mathbf{0 . 2 8} \\
{[0.150 .43]}\end{array}$ & 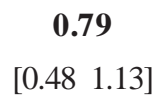 & $\begin{array}{c}\mathbf{0 . 8 6} \\
{[0.491 .3]}\end{array}$ & $\begin{array}{c}\mathbf{0 . 8 7} \\
{[0.46 \quad 1.32]}\end{array}$ \\
\hline Spillovers from EM7 plus South Africa & $\begin{array}{c}\mathbf{0 . 2 9} \\
{[0.160 .44]}\end{array}$ & 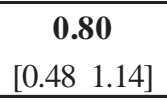 & 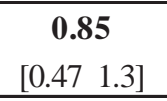 & $\begin{array}{c}\mathbf{0 . 8 4} \\
{[0.44 \quad 1.31]}\end{array}$ \\
\hline $\begin{array}{l}\text { Spillovers from EM7 plus Hong Kong } \\
\text { SAR, China }\end{array}$ & $\begin{array}{c}\mathbf{0 . 2 8} \\
{[0.160 .42]}\end{array}$ & 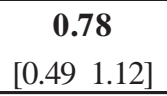 & 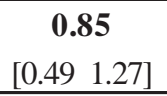 & 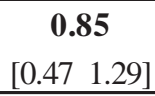 \\
\hline Spillovers from EM7 plus Singapore & $\begin{array}{c}\mathbf{0 . 2 8} \\
{[0.160 .42]}\end{array}$ & $\begin{array}{c}\mathbf{0 . 7 9} \\
{[0.51 .11]}\end{array}$ & $\begin{array}{c}\mathbf{0 . 8 7} \\
{\left[\begin{array}{ll}0.51 & 1.28\end{array}\right]}\end{array}$ & 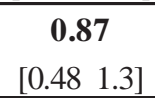 \\
\hline Spillovers from EM7 plus Korea Rep. & $\begin{array}{c}\mathbf{0 . 2 8} \\
{[0.16 \quad 0.41]}\end{array}$ & $\begin{array}{c}\mathbf{0 . 7 7} \\
{[0.491 .1]}\end{array}$ & 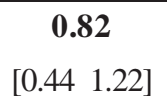 & 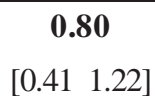 \\
\hline
\end{tabular}

Note: The table shows the cumulated impulse responses of growth in other EFM, for different horizons, due to a 1 percentage point increase on impact in EM7 growth. These are from the aggregate model using alternative definitions of large EM as spillover source. Bolded denote the medians and the numbers in the parentheses are the 16-84 percent confidence bands. Spillovers from EM7 plus South Africa: spillover source is the group of EM7 countries and South Africa. The spillover destination in this case is other EFM minus South Africa; Spillovers from EM7 plus Hong Kong SAR, China: spillover source is the group of EM7 countries and Hong Kong SAR, China; Spillovers from EM7 plus Singapore: spillover source is the group of EM7 countries and Singapore; Spillovers from EM7 plus Korea Rep.: spillover source is the group of EM7 countries and Korea Republic. 
Figure A1: Spillovers from China: Commodity exporters vs. commodity importers

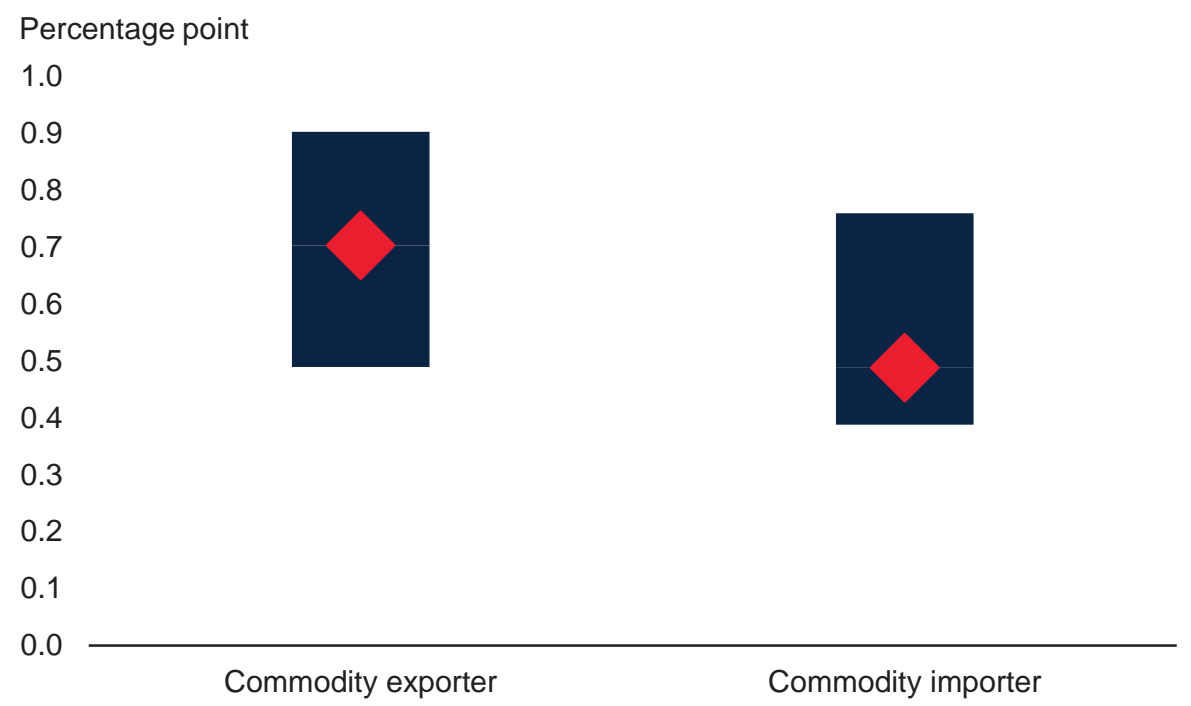

Note: The graphs show the cumulated impulse responses at the end of three years due to a 1 percentage point increase on impact in China's growth. These are estimated using the country models. In each group, the bar denotes the crosssectional 20-80 percentile range of the responses of other EFM economies in that group and the red diamond denotes the respective cross-sectional average response. Commodity exporters include Chile, Costa Rica, Malaysia, Paraguay, and Peru. Commodity importers include Bulgaria, Croatia, Hungary, Jordan, Poland, Republic of Korea, Romania, and Thailand.

Figure A2: Impulse responses due to a 1 percentage point increase in G7 and EM7 growth: Robustness

Percentage point

1.8

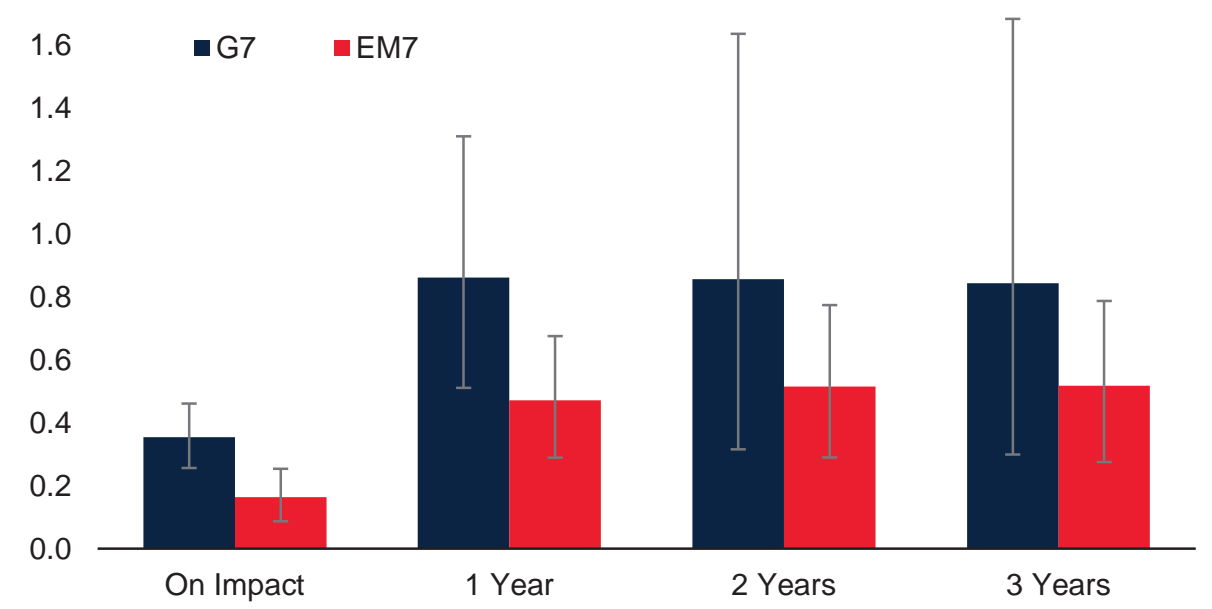

Note: The graphs show the cumulated impulse responses of growth in other EFM, at different horizons, due to a 1 standard deviation increase on impact in G7 and EM7 growth. Solid bars represent medians, and error bars represent 16-84 percent confidence bands. 
Figure A3: Impulse responses due to a 1 percentage point increase in EM7 and China's growth: Robustness

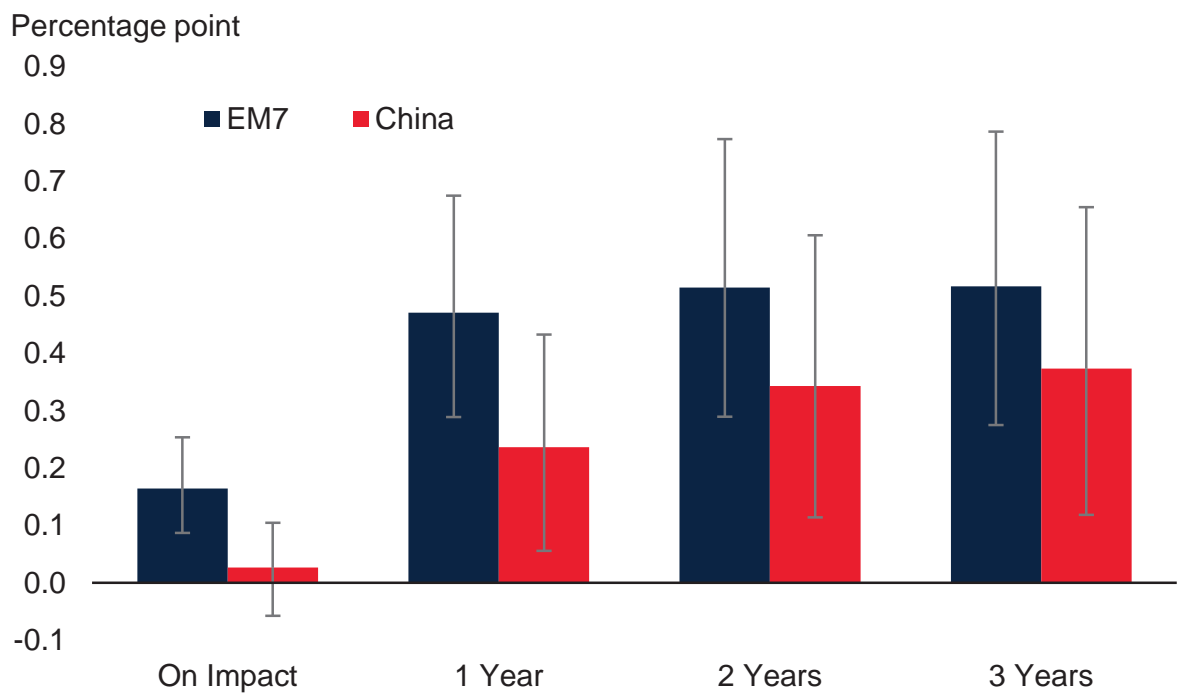

Note: The graphs show the cumulated impulse responses of growth in other EFM, at different horizons, due to a 1 standard deviation increase on impact in EM7 and China's growth. Solid bars represent medians, and error bars represent 16-84 percent confidence bands.

Figure A4: Impulse responses due to a 1 percentage point increase in growth in individual EM7: Robustness

\section{A. Aggregate spillovers}

Percentage point

1.2

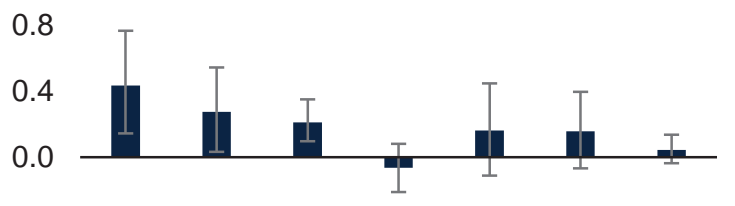

$-0.4$

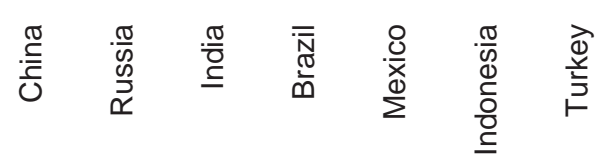

\section{B. Country spillovers}

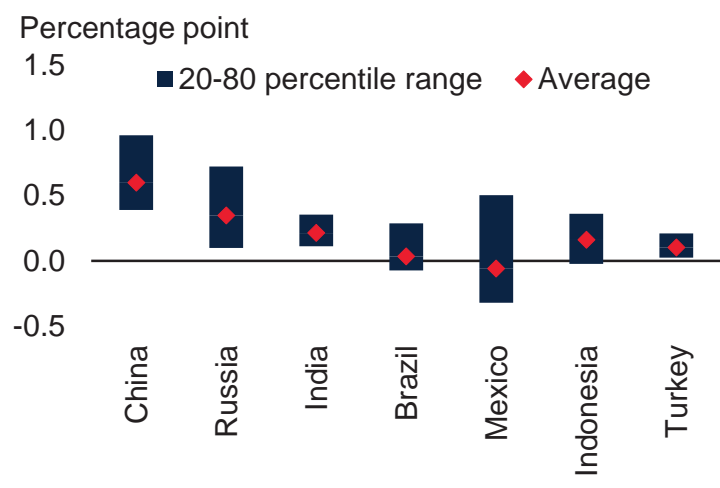

Note:

A. The graph shows cumulated impulse responses of growth in other EFM at the end of two years due to a 1 percentage point increase on impact in each of the EM7 growth. These results are from the aggregate VAR model. Solid bars represent medians, and the error bands represent 16-84 percent confidence bands.

B. The graph shows the cumulated impulse responses at the end of two years due to a 1 percentage point increase on impact in each of the EM7 growth. These results are from the country models. For each spillover source country, the bar denotes the cross-sectional 20-80 percentile range of the responses of other EFM economies and the red diamond denotes the cross-sectional average response. 
Figure A5: Contribution of EM7 (G7) and the next three largest EM (AM) to EM (AM) output

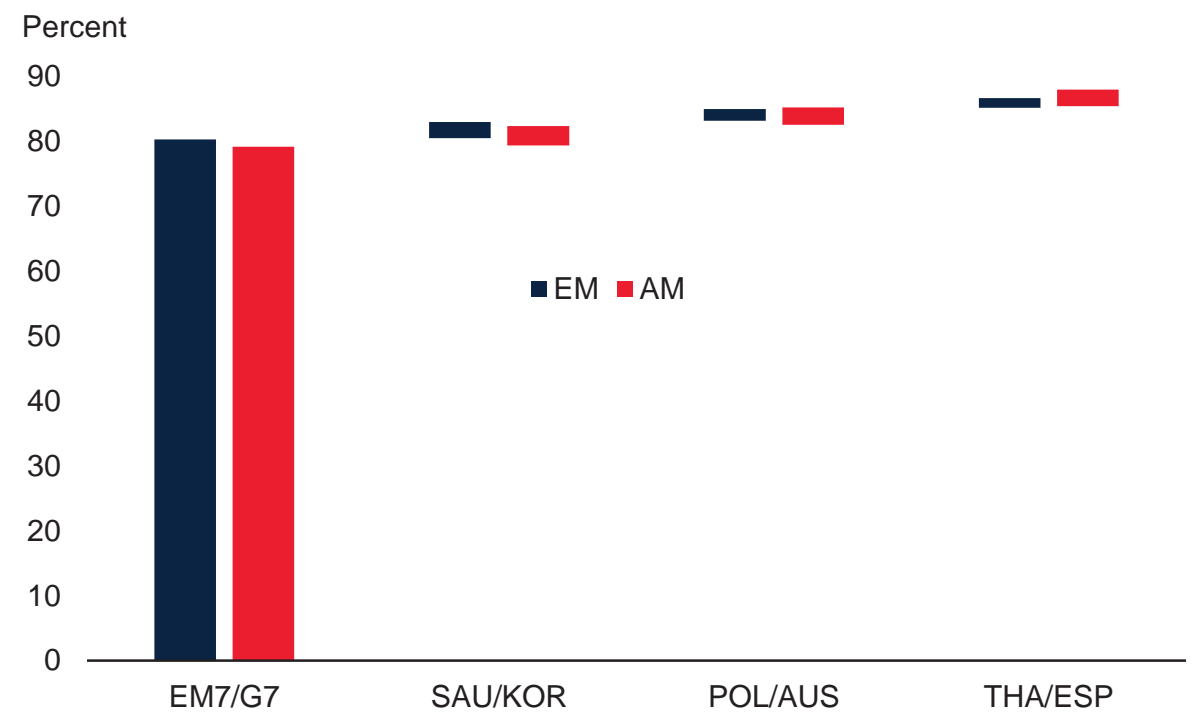

Note: The blue bars show the EM output share of EM7 and those of the next three largest EM: Saudi Arabia (SAU), Poland (POL), and Thailand (THA). The red bars show the AM output share of G7 and those of the next three largest AM: Korea Republic (KOR), Australia (AUS), and Spain (ESP). 